\title{
DIREITO, TRABALHO E VULNERABILIDADE
}

\section{LAW, LABOR, AND VULNERABILITY}

\author{
Universidade Federal de Ouro Preto - UFOP - (Ouro Preto, Minas Gerais, Brasil)
}

Recebimento: 14 dez. 2018

Aceitação: 22 jul. 2019

\begin{abstract}
Como citar este artigo / How to cite this article (informe a data atual de acesso / inform the current date of access):
\end{abstract}
ALVES, Amauri Cesar. Direito, trabalho e vulnerabilidade. Revista da Faculdade de Direito UFPR, Curitiba, PR, Brasil, v. 64, n. 2, p. 111-139, maio/ago. 2019. ISSN 2236-7284. Disponível em: https://revistas.ufpr.br/direito/article/view/63907. Acesso $\quad$ em: $31 \quad$ ago. $2019 . \quad$ DOI: http://dx.doi.org/10.5380/rfdufpr.v64i2.63907.

\section{RESUMO}

O presente artigo tem por objetivo propor conceito de vulnerabilidade a ser desenvolvido no âmbito do Direito do Trabalho, além de apresentar possibilidades de sua aplicação em casos concretos que envolvem prestação laborativa, com ou sem vínculo empregatício. Será possível compreender a vulnerabilidade em contexto trabalhista como situação de inferioridade contratual agravada por fatores de risco laboral ou pela condição pessoal do trabalhador, seja ele empregado ou não, que poderá resultar em lesão em sua esfera patrimonial ou existencial. O presente estudo desenvolve a ideia de vulnerabilidade para justificar a ampliação da proteção normativa própria do Direito do Trabalho. A partir da identificação de vulnerabilidades poderá o intérprete, em situações jurídicas complexas, aplicar a estrutura de proteção social justrabalhista a trabalhadores que não são empregados em razão de ausência de elemento fático-jurídico caracterizador do vínculo empregatício.

\section{PALAVRAS-CHAVE}

Vulnerabilidade. Proteção. Trabalho.

\section{ABSTRACT}

This article aims to propose a concept of vulnerability to be developed in the scope of Labor Law, besides presenting possibilities of its application in concrete cases that involve labor provision, with or without employment relationship. It will be possible to understand the vulnerability in the labor context as a situation of contractual inferiority exacerbated by occupational risk factors or by the personal condition of the worker, whether employed or not, which could result in injury in their patrimonial or existential sphere. The present study develops the idea of vulnerability to justify the expansion of normative protection proper of Labor Law. From the identification of vulnerabilities, the interpreter can apply the structure of social protection to workers who are not employed because of the absence of a legal-juridical element that characterizes the employment relationship in complex legal situations.

\section{KEYWORDS}

Vulnerability. Protection. Labor. 


\section{INTRODUÇÃO}

O presente artigo tem como objetivos compreender o conceito de vulnerabilidade no contexto do atual Direito Privado brasileiro e construir propostas de sua aplicação no âmbito do Direito do Trabalho, a partir da sugestão e estruturação de uma conceituação própria, que é o ponto central da análise a ser desenvolvida.

Não é incomum decisão judicial trabalhista que se refere à vulnerabilidade do trabalhador em perspectiva prática, mas são excepcionais aquelas que lhe delimitam o conteúdo jurídico. Raros também são os estudos acadêmicos que se dedicam ao tema, com exceções aqui citadas. Assim, é necessário estabelecer os contornos justrabalhistas do conceito de vulnerabilidade, bem como fixar mínima e inicialmente os efeitos de sua aplicação no plano fático.

Para que seja possível trazer a noção de vulnerabilidade para o contexto trabalhista será relevante, de início, traçar seus conceitos em outras ciências, com destaque para a Sociologia do Trabalho. Em seguida será necessário fixar distinções entre vulnerabilidade e os contornos jurídicos da hipossuficiência. É importante também analisar como o Direito do Trabalho se relaciona com os tipos de vulnerabilidade (negocial, hierárquica, econômica, técnica, informacional, psíquica e ambiental) consagrados na doutrina, com a busca, sempre que possível, de experiências na realidade fática da prestação laborativa. É relevante também que se pense a vulnerabilidade no contexto do elemento central da relação de emprego, trazendo seus contornos para os debates relativos à subordinação, supersubordinação, sujeição pessoal e objetificação do trabalhador.

A análise teórica em perspectiva jurídica tem por referências as obras de Cláudia Lima Marques, Bruno Miragem, Carlos Nelson Konder e Leandro do Amaral D. de Dorneles. Os dois primeiros autores desenvolvem o conceito de vulnerabilidade principalmente na perspectiva do Direito do Consumidor, ramo jurídico que inaugura tal teorização no direito brasileiro e que servirá de balizamento para a análise justrabalhista. Carlos Nelson Konder trata do Direito Privado em geral e em especial do Direito Civil. É importante também a contribuição de Leandro do Amaral D. de Dorneles, que, salvo melhor juízo, faz a primeira aproximação entre o Direito do Trabalho e as teorias da vulnerabilidade.

O artigo se estrutura em dois eixos. O desenvolvimento se dará por meio da análise das construções teóricas sobre a vulnerabilidade e da tentativa de se compreender novos sujeitos da proteção trabalhista a partir de seu conceito justrabalhista.

A ideia é de revisão bibliográfica no primeiro eixo, para que seja possível, ao final, propor um conceito próprio, novo, específico de vulnerabilidade que compreenda o trabalhador enquanto 
sujeito envolvido em uma relação capital-trabalho. No segundo eixo o que se pretende é a aplicação do novo conceito a situações específicas de vulnerabilidade do trabalhador que não é empregado, mas que deve ser destinatário de proteção estatal.

A partir do conceito a ser construído será possível, em tese, trabalhar a ideia de vulnerabilidade em três vertentes: aprofundamento da proteção a empregados, restrição à precarização das relações pela via da normatização heterônoma e ampliação da esfera de proteção para trabalhadores que não são empregados. Dois serão basicamente os efeitos de tais compreensões: a identificação de novos sujeitos da proteção trabalhista e a proposição de novas teorias, novas práticas e revisão de conceitos e institutos justrabalhistas tradicionais. Em síntese, novos direitos e novos sujeitos decorrentes do aprofundamento teórico das teorias da vulnerabilidade no âmbito do Direito do Trabalho. No presente estudo, entretanto, somente uma das três vertentes receberá análise detida, que é de a ampliação da proteção trabalhista para trabalhadores que não são empregados.

Pretende-se, então, trazer a ideia de vulnerabilidade para o centro do Direito do Trabalho, principalmente sua aplicação no plano fático das diversas relações trabalhistas existentes, para que se possa ao final reconhecer novos sujeitos da proteção.

\section{VULNERABILIDADE: CONCEITOS, CONTEXTOS E DISTINÇÕES}

O tema da vulnerabilidade vem se desenvolvendo amplamente no Direito Privado, com destaque especial para a construção doutrinária consumerista. Para efeito do presente estudo a conceituação e as distinções relativas ao tema da vulnerabilidade têm aspecto central, pois a partir delas será possível construir compreensões teóricas e práticas também no âmbito do Direito do Trabalho.

Preliminarmente à análise jurídica serão vistos conceitos trazidos pelo léxico e por outros ramos do conhecimento. De início a definição de Houaiss como uma primeira aproximação com a ideia de vulnerável: “ferido, sujeito a ser atacado, derrotado: frágil, prejudicado ou ofendido” (VULNERÁVEL, 2009, p. 1.961). Percebe-se então desde já a fragilidade daquele que é sujeito a ser ferido, ofendido, prejudicado. Assim, a vulnerabilidade estaria relacionada à potencialidade de ser atacado, derrotado, prejudicado, ofendido.

A Assistência Social traz definição do que seja vulnerabilidade social:

Vulnerabilidade social apresenta-se como uma baixa capacidade material, simbólica e comportamental de famílias e pessoas para enfrentar e superar os desafios com os quais se defrontam, dificultando o acesso à estrutura de oportunidades sociais, econômicas e culturais que provêm do Estado, do mercado e da Sociedade. Refere-se a uma diversidade de 
“situações de risco” determinadas por fatores de ordem física, pelo ciclo de vida, pela etnia, por opção pessoal etc, que favorecem a exclusão e/ou que inabilita e invalida, de maneira imediata ou no futuro, os grupos afetados (indivíduos, famílias), na satisfação de seu bemestar - tanto de subsistência quanto de qualidade de vida (PREFEITURA MUNICIPAL DE BELO HORIZONTE, 2007).

Importantes noções iniciais decorrem do conceito acima: baixa capacidade do cidadão para superar dificuldades, em razão de situações que favorecem sua exclusão, com potencial impacto em sua subsistência e qualidade de vida. Refere-se a uma diversidade de situações de risco, determinadas por múltiplos fatores.

É relevante para a compreensão da vulnerabilidade em perspectiva justrabalhista a sua construção teórica na Sociologia do Trabalho. A ideia de vulnerabilidade, aqui, relaciona-se com a precarização do trabalho que é inerente ao capitalismo do final do século XX e início do século XXI, que pretende afastar a interferência estatal na relação trabalhista. Inicialmente Marcio Pochmann aproxima o conceito de vulnerabilidade com a ideia que poderá ser apresentada ao final do presente estudo. Tratando da realidade sociolaboral do final do século passado, que muito se aproxima da atual, o autor correlaciona vulnerabilidade social com políticas neoliberais, desemprego, desigualdade social e exclusão:

O distanciamento atual de uma situação de pleno emprego e as mutações nas condições e relações de trabalho e no status do assalariado permitem observar com maior clareza uma ruptura na trajetória de identificação social e de integração comunitária. E, com isso, o surgimento de novas vulnerabilidades sociais no capitalismo torna-se por si só um elemento fundante da exclusão social que se generaliza neste final de século.

$[\ldots]$

Não parece haver dúvidas, portanto, de que a definição de um novo padrão de integração social está ainda por ser desenvolvida. Todavia, é preciso compreender que o Estado necessitaria exercer um papel relevante na luta contra a exclusão social, principalmente no que diz respeito ao enfrentamento do problema do desemprego e das ocupações precárias nas economias avançadas. Sem isso, novas vulnerabilidades sociais tendem a ganhar maior espaço neste final de século (POCHMANN, 1999, p. 11, 23-24).

Aqui a vulnerabilidade social se relaciona diretamente com as relações de trabalho. Inobstante a análise transcrita refletir o final do século XX, o neoliberalismo precarizante está de volta ao Brasil e influencia diretamente a relação de emprego e a noção justrabalhista de vulnerabilidade.

Graça Druck trata de vulnerabilidade social no contexto da atual precarização do trabalho no sistema produtivo pós-fordista ou de reestruturação produtiva, valendo-se parcialmente da análise de Castel sobre o tema:

Trata-se, segundo Castel (1998), da precarização do trabalho como elemento central da nova dinâmica do desenvolvimento do capitalismo, criando uma nova condição de vulnerabilidade social: um processo social que modifica as condições do assalariamento (estável) 
anteriormente hegemônico no período da chamada sociedade salarial ou fordista. A perda do emprego ou a perda da condição de uma inserção estável no emprego cria uma condição de insegurança e de um modo de vida e de trabalho precários, nos planos objetivo e subjetivo, fazendo desenvolver a ruptura dos laços e dos vínculos, tornando-os vulneráveis e sob uma condição social fragilizada, ou de “desfiliação" social (CASTEL apud DRUCK, 2011, p. 41).

Aqui é relevante compreender a vulnerabilidade social como estratégia capitalista tendente a fragilizar os antigos modelos de relação capital-trabalho que eram inerentes ao sistema fordista de produção. Ao invés de vínculos formais, perenes, protegidos e que permitiam boa inserção do trabalhador no mercado de consumo, agora as relações são informais, de curta duração, desprotegidas. Marcelo Weishaupt Proni (2013, p. 841) traz importante contribuição para a conceituação de trabalhador vulnerável na literatura internacional, como se percebe:

Por sua vez, na literatura internacional, é comum encontrar estudos que utilizam a expressão “trabalhador vulnerável” (vulnerable worker) como um sinônimo de trabalhador em situação precária. Entretanto, o conceito também tem sido definido de maneiras variadas e empregado com diferentes finalidades. Uma abordagem frequente é aquela que define os grupos de trabalhadores cuja condição ocupacional coloca em risco seu bem-estar, tais como os trabalhadores por conta própria que não estão cobertos pela legislação trabalhista, os empregados que se sujeitam a abusos do empregador por medo de perder o emprego, aqueles que não têm acesso ao benefício do seguro-desemprego ou a planos de saúde e aposentadoria e os que não encontram trabalho regular e passam muito tempo recebendo baixos rendimentos (Saunders, 2003). Em outros documentos, o termo "vulnerabilidade” tem um escopo mais estreito, circunscrito a situações em que há alto risco de serem negados os direitos do trabalhador, e este não tem capacidade ou meios de fazer valer seus direitos, como no caso de imigrantes (United Kingdom-DTI, 2006). E há abordagens alternativas: por exemplo, em artigo recente, os trabalhadores vulneráveis são identificados pela combinação entre baixa remuneração e falta de representação sindical associadas com a exclusão do sistema público de proteção ao trabalho (Pollert; Charlwood, 2009).

Destaca-se o risco a que se submete o trabalhador em determinadas situações fáticas e contratuais. O supracitado autor trata também do tema na literatura especializada nacional:

No Brasil, a análise da vulnerabilidade no mercado de trabalho tem enfatizado as características pessoais que conferem desvantagens competitivas e tem destacado as formas de inserção precária que correspondem a uma condição intermediária entre o desemprego e o trabalho decente (Dieese; Unicamp, 2007). Por fim, convém ressaltar que os diagnósticos mais pertinentes costumam elencar um gradiente de vulnerabilidades no mercado de trabalho, podendo variar bastante a metodologia adotada e os critérios para definir a "vulnerabilidade ocupacional” (PRONI, 2013, p. 841).

Conforme será visto adiante, é possível, na mesma linha de Marcelo Weishaupt Proni, relacionar vulnerabilidade com trabalho decente, na medida em que aquela se revela ou se amplia quando este não se mostra presente.

Ricardo Antunes e Graça Druck tratavam, em 2015, da vulnerabilidade estrutural em que estavam inseridos trabalhadores brasileiros, principalmente os terceirizados: 
Assim, quando se examina a dimensão “mercado de trabalho”, isto é, as formas de mercantilização da força de trabalho, encontra-se uma condição de heterogeneidade e segmentação, marcada por uma vulnerabilidade estrutural que se reconfigura, com formas de inserção (contratos) precárias, sem proteção social, com salários mais baixos, revelados pela terceirização de forma exemplar, cujo crescimento exponencial pode ser observado em diferentes segmentos da classe trabalhadora (ANTUNES; DRUCK, 2015, p. 25).

A vulnerabilidade dos trabalhadores terceirizados tende a ser ampliada após a Reforma Trabalhista, que agora permite a avença trilateral em qualquer atividade do tomador dos serviços.

O desemprego assume, nesse contexto neoliberal precarizante, um papel relevante, ao impor, à classe trabalhadora como um todo (empregados, subempregados, desempregados, desalentados), redução de seu patamar contratual. O falecido filósofo húngaro de formação marxista István Mészáros, que também lecionou Ciências Sociais, explica que o desemprego passa a ser uma tendência socioeconômica que aprofunda a crise estrutural do capital atual:

Como resultado dessa tendência, o problema não mais se restringe à difícil situação dos trabalhadores não-qualificados, mas atinge também um grande número de trabalhadores altamente qualificados, que agora disputam, somando-se ao estoque anterior de desempregados, os escassos - e cada vez mais raros - empregos disponíveis. Da mesma forma, a tendência da amputação "racionalizadora” não está mais limitada aos "ramos periféricos de uma indústria obsoleta”, mas abarca alguns dos mais desenvolvidos e modernizados setores da produção - da indústria naval e aeronáutica à eletrônica, e da indústria mecânica à tecnologia espacial (MÉSZÁROS, 2009, p. 69).

Será possível perceber no presente estudo que a vulnerabilidade como fator de risco se mostra cada vez mais relevante quanto maior o número de desempregados e trabalhadores informais no mercado. São trabalhadores vulneráveis como regra geral e conforme será visto, mas, para além deles, o risco do desemprego também influencia os padrões contratuais daqueles que estão empregados, que passam a se sujeitar a situações com as quais antes não consentiriam.

Estabelecidas as conceituações e contextos preliminares, com destaque para aspectos sociológicos, é possível pesquisar as construções jurídicas sobre a vulnerabilidade. De início a obra que parece ser referencial sobre o tema, de Cláudia Lima Marques e Bruno Miragem, que estudam mais detidamente a vulnerabilidade na perspectiva do Direito do Consumidor:

Poderíamos afirmar, assim, que a vulnerabilidade é mais um estado da pessoa, um estado inerente de risco ou um sinal de confrontação excessiva de interesses identificado no mercado, é uma situação permanente ou provisória, individual ou coletiva, que fragiliza, enfraquece o sujeito de direitos, desequilibrando a relação (MARQUES; MIRAGEM, 2014, p. 120).

Aqui é importante desde já destacar as principais características da vulnerabilidade no conceito de Cláudia Lima Marques e Bruno Miragem. Percebe-se situação inerente à pessoa e que 
pode ser permanente ou provisória, individual ou coletiva. Na essência essa situação pessoal fragiliza o cidadão e faz com que se coloque em posição de inferioridade contratual.

No âmbito do direito privado em geral há amplo espaço para a proteção especial dos vulneráveis. A ideia básica, aqui expressa por Claudia Lima Marques e Bruno Miragem, é que não se pode "prescindir do reconhecimento da fraqueza de certos grupos da sociedade, que afinal se apresenta como ponto de encontro entre a função individual que lhe é reconhecida, e sua função social, afirmada no direito privado solidário que emerge da Constituição.” (MARQUES; MIRAGEM, 2014, p. 17). Tal construção recente, que alcança também o Direito Civil, desconstrói paradigmas anteriores que insistiam, historicamente, em distinguir em planos estanques e claramente apartados direito público e direito privado (MARQUES; MIRAGEM, 2014). A ideia prevalente até o final do século passado, de que no plano do direito privado não cabe intervenção estatal, vem sendo gradativamente desconstruída, o que é importante na perspectiva da melhor interpretação constitucional no Brasil.

Seguem Cláudia Lima Marques e Bruno Miragem, em conceituação que vem sendo amplamente adotada no Brasil para os mais diversos contornos jurídicos, para além do Direito do Consumidor:

Poderíamos afirmar, assim, que a vulnerabilidade é mais um estado da pessoa, um estado inerente de risco ou um sinal de confrontação excessiva de interesses identificado no mercado, é uma situação permanente ou provisória, individual ou coletiva, que fragiliza, enfraquece o sujeito de direitos, desequilibrando a relação. A vulnerabilidade não é, pois, o fundamento das regras de proteção do sujeito mais fraco, é apenas a "explicação" destas regras ou da atuação do legislador, é a técnica para as aplicar bem, é a noção instrumental que guia e ilumina a aplicação destas normas protetivas e reequilibradoras, à procura do fundamento da Igualdade e da Justiça equitativa (MARQUES; MIRAGEM, 2014, p. 120).

Diante do conceito consumerista aqui citado há que se destacar a noção de que a vulnerabilidade não se presta à fundamentação das regras de proteção, sendo instrumento de compreensão das regras, ferramenta para melhor aplicação do direito.

Cláudia Lima Marques e Bruno Miragem (2014, p. 1.117) explicam que “a igualdade supõe uma comparação, um contexto, uma identificação no caso”, exigindo, portanto, uma análise que quase sempre é casuística. Neste contexto, que os autores identificam como moderno, não haveria espaços para que alguém possa ser e continuar a ser diferente, o que exigiria, no mundo atual, uma conceituação pós-moderna (MARQUES; MIRAGEM, 2014). O direito à diferença, mais recente, tende a ser preservado pela ideia de vulnerabilidade. Relatam os autores que "os novos estudos europeus sobre a vulnerabilidade propõem sua distinção conceitual em relação ao conceito de 
igualdade ou desigualdade entre sujeitos” (MARQUES; MIRAGEM, 2014, p. 119). E explicam, estabelecendo distinção com relação à ideia de vulnerabilidade:

Isso porque o paradigma de igualdade parte de uma visão macro, do homem e da sociedade, noção mais objetiva e consolidada, onde a desigualdade se aprecia sempre pela comparação de situações e pessoas, de acordo com a máxima aristotélica: tratar igualmente os iguais, e desigualmente aos desiguais, na medida da sua desigualdade, para alcançar o justo. Já a vulnerabilidade é filha deste princípio, mas noção flexível e não consolidada, com os traços de subjetividade que a caracterizam: a vulnerabilidade não necessita sempre de uma comparação entre situações e sujeitos (MARQUES; MIRAGEM; 2014, p. 120).

Aqui é importante um alerta preliminar, no sentido de não se permitir, a partir do conceito de vulnerabilidade trazido para o Direito do Trabalho, a fragmentação, hierarquização ou pulverização da proteção estatal laboral de empregados. Não há que se falar, com base na teorização até aqui trazida, em redução da esfera de proteção laboral de acordo com a menor vulnerabilidade do trabalhador empregado. A ideia é ampliar a esfera protetiva no âmbito das relações capital-trabalho.

Por fim, no que concerne às conceituações, a importante e seminal contribuição de Leandro do Amaral D. de Dorneles sobre a vulnerabilidade no âmbito do Direito do Trabalho:

\begin{abstract}
Trata-se da noção instrumental que guia a aplicação das normas protetivas, visando à igualdade e à justiça equitativa. Enquanto o princípio da igualdade decorre de uma visão mais abstrata do indivíduo e da sociedade, estabelecendo contornos objetivos de equilíbrios ou desequilíbrios entre as relações humanas, a vulnerabilidade é uma noção "flexível”, que apresenta "traços de subjetividade", não necessitando sempre de uma comparação entre situações e sujeitos (DORNELES, 2013, p. 294).
\end{abstract}

Diante dos conceitos expostos é possível compreender a vulnerabilidade, em perspectiva jurídica, como estado da pessoa que se encontra fragilizada. A percepção da vulnerabilidade atuaria como instrumento de interpretação e aplicação da norma jurídica, e não necessariamente para fundamentar uma regra estatal diferente para uma situação específica.

Carlos Nelson Konder também traz sua contribuição para o debate. Inicialmente, ao citar Heloísa Helena Barboza, traz compreensão que será importante para a aplicação da ideia de vulnerabilidade nas relações laborativas, embora nenhum dos dois trate especificamente do contrato de trabalho:

Todos os humanos são, por natureza, vulneráveis, visto que todos os seres humanos são passíveis de serem feridos, atingidos em seu complexo psicofísico. Mas nem todos serão atingidos do mesmo modo, ainda que se encontrem em situações idênticas, em razão de circunstâncias pessoais, que agravam o estado de suscetibilidade que lhe é inerente. Embora em princípio iguais, os humanos se revelam diferentes no que respeita à vulnerabilidade. (BARBOZA apud KONDER, 2015, p. 103).

Os empregados celetistas são iguais quanto à sua hipossuficiência, conforme será visto. Como regra geral são explorados para que seu empregador possa extrair do trabalho ganhos 
econômicos, independentemente de quem seja o trabalhador. Embora todos sejam hipossuficientes por definição, nem todos podem se dizer vulneráveis, pois há circunstâncias fáticas e jurídicas que podem agravar a hipossuficiência inerente ao emprego.

Carlos Nelson Konder destaca que parte da doutrina entende a vulnerabilidade como restrita à esfera patrimonial do sujeito contratante, identificando como situações de hipervulnerabilidade aquelas que envolvam ameaça à existência digna e não só ao patrimônio. O citado autor, entretanto, prefere tratar o que para alguns seria hipervulnerabilidade como vulnerabilidade existencial. (KONDER, 2015, p. 105). Diferentemente do que parecem concluir Cláudia Marques e Bruno Miragem, entende Carlos Nelson Konder que a vulnerabilidade existencial justifica proteção normativa específica. Para tanto apresenta distinção entre vulnerabilidade patrimonial e vulnerabilidade existencial, visto que

a vulnerabilidade existencial seria a situação jurídica subjetiva em que o titular se encontra sob maior suscetibilidade de ser lesionado na sua esfera extrapatrimonial, impondo a aplicação de normas jurídicas de tutela diferenciada para a satisfação do princípio da dignidade da pessoa humana.

Diferencia-se da vulnerabilidade patrimonial, que se limita a uma posição de inferioridade contratual, na qual o titular fica sob a ameaça de uma lesão basicamente ao seu patrimônio, com efeitos somente indiretos à sua personalidade. Diante disso, a intervenção reequilibradora do ordenamento no caso de vulnerabilidade patrimonial costuma ser viabilizada com recurso aos instrumentos jurídicos tradicionalmente referidos às relações patrimoniais, como a invalidade de disposições negociais e a reponsabilidade, com imposição da obrigação de indenizar.

Já no caso da vulnerabilidade existencial, a utilização desses recursos clássicos, se necessária, deve ser feita com cuidado pelo intérprete, tendo em vista que são técnicas que não foram construídas para a satisfação desses fins e podem, em grande medida, se revelar incompatíveis com os valores em jogo. O ideal, para a plena implementação da dignidade da pessoa humana, é a construção e utilização de mecanismos próprios, processo este que, embora ainda incipiente e em grande necessidade de sistematização, já se pode observar de forma fragmentária e experimental (KONDER, 2015, p. 105).

A compreensão diferente talvez se justifique em razão de os consumeristas citados tratarem da relação patrimonial decorrente do consumo, enquanto o foco do autor civilista está, aqui, no aspecto extrapatrimonial, ou de existência digna da pessoa. Cita Carlos Nelson Konder a atuação específica do legislador em relação à vulnerabilidade existencial, com exemplos referentes à defesa das crianças e adolescentes, dos idosos, pessoas com deficiência e até mesmo das mulheres em relação à violência e ao trabalho. Muito embora reconheça situações especiais, sugere o autor cuidado com a criação de categorias:

Esse panorama revela que a criação de categorias, embora possa ser útil em alguns casos, é prescindível. O fundamental, dessa forma, é reconhecer que a vulnerabilidade existencial prescinde de qualquer tipificação, eis que decorrência da aplicação direta dos princípios constitucionais da dignidade da pessoa humana e da solidariedade social, devendo sempre ser avaliada em atenção às circunstâncias do caso concreto (KONDER, 2015, p. 106). 
Tal alerta, como visto, deve ser também considerado no plano justrabalhista, em que há riscos na categorização, uma vez que historicamente os empregadores capitalistas se valem disso para rebaixar o status básico da proteção, ao invés de elevar o patamar jurídico da proteção aos trabalhadores.

Especificamente em contornos justrabalhistas é possível, desde já, ensaiar um conceito de vulnerabilidade como situação de inferioridade contratual agravada por fatores de risco laboral ou pela condição pessoal do trabalhador, seja ele empregado ou não, que poderá resultar em lesão em sua esfera patrimonial ou existencial. Perceba-se que essa definição de vulnerabilidade é necessariamente relacional, e não situacional. A análise da vulnerabilidade interessa para o Direito do Trabalho, em perspectiva restrita ou ampliada, se e quando o trabalhador se insere em uma relação com alguém que lhe absorve mão de obra ou saber-fazer. Enfim, a vulnerabilidade para fins de Direito do Trabalho está necessariamente vinculada à inserção laborativa contratual do trabalhador (relação de trabalho ou emprego), sem a qual não se justifica a análise específica.

Em síntese inicial é possível compreender que todo trabalhador, em sua relação com o capital, posiciona-se em situação fática de desigualdade contratual, mas alguns trabalhadores terão sua relação ainda mais fragilizada em razão de estado ou condição específicos. Essa fragilidade agravada poderá mais facilmente resultar em lesão patrimonial ou existencial ao trabalhador na sua relação com o contratante detentor do capital.

Tão importante quanto a conceituação preliminar é a fixação das distinções, ou seja, daquilo que não é exatamente vulnerabilidade na perspectiva justrabalhista.

\subsection{VULNERABILIDADE E HIPOSSUFICIÊNCIA}

Pouco sentido haveria na análise aqui empreendida se ao final se compreendesse a ideia de vulnerabilidade no mesmo plano da já bem consolidada noção de hipossuficiência do trabalhador. Assim, talvez mais importante do que fixar conceitos será estabelecer distinções entre vulnerabilidade e hipossuficiência. É importante destacar, desde já, que a distinção aqui proposta não se dá nos termos consagrados no Direito do Consumidor, como se infere das lições de Humberto Theodoro Júnior (2004, p. 143), que trata assim da hipossuficiência:

\footnotetext{
Trata-se de impotência do consumidor, seja de origem econômica seja de outra natureza, para apurar e demonstrar a causa do dano cuja responsabilidade é imputada ao fornecedor. Pressupõe uma situação em que concretamente se estabeleça uma dificuldade muito grande para o consumidor de desincumbir-se de seu natural onus probandi, estando o fornecedor em melhores condições para dilucidar o evento danoso.
} 
A hipossuficiência, para o Direito do Consumidor, tem impactos restritos à matéria processual, o que não se dá no âmbito justrabalhista. É necessário então brevemente estabelecer conceitos de hipossuficiência. Houaiss define hipossuficiente como a "pessoa de parcos recursos econômicos, que não é autossuficiente.” (HIPOSSUFICIENTE, 2009, p. 1.027). Leandro do Amaral D. de Dorneles (2013) relata que a doutrina clássica relaciona a hipossuficiência com a desigualdade econômica existente entre empregado e empregador. O referido autor cita Cesarino Júnior, que por sua vez estabelece que “aos não proprietários, que só possuem sua força de trabalho, denominamos hipossuficientes. Aos proprietários de capitais, imóveis, mercadorias, maquinaria, terras, chamamos autossuficientes.” (CESARINO JÚNIOR apud DORNELES, 2013, p. 294). Maurício Godinho Delgado define o Princípio da Proteção, basilar do Direito do Trabalho, em torno da hipossuficiência do trabalhador, uma vez que o ramo jurídico especializado estrutura "uma teia de proteção à parte hipossuficiente na relação empregatícia - o obreiro -, visando retificar (ou atenuar), no plano jurídico, o desequilíbrio inerente ao plano fático do contrato de trabalho.” (DELGADO, 2017, p. 213).

É possível compreender então que todo empregado é hipossuficiente em decorrência de se posicionar contratualmente como tal na relação de emprego, uma vez que no plano fático sua situação ante o empregador é de parte mais fraca da avença empregatícia. Tal situação é decorrente não só da subordinação jurídica inerente à relação de emprego, mas, também e talvez principalmente, da concentração de poderes no lado patronal do contrato de trabalho. No sistema capitalista o Direito do Trabalho responde aos anseios patronais por preservação do poder e manutenção do status quo, sem perder de vista, até a "Reforma Trabalhista” pelo menos, a face protetiva do cidadão trabalhador.

Leandro do Amaral D. de Dorneles, com base na tese de doutorado de Carmen Camino, destaca que a ideia de vulnerabilidade é mais ampla, de maior complexidade do que a de hipossuficiência, e “abrange um maior número de variáveis na sua definição, tornando-a mais complexa, porém mais maleável e adequada [...] para retratar o diversificado mundo do trabalho contemporâneo.” (DORNELES, 2013, p. 294).

A hipossuficiência, por sua fundamentação na posição contratual do empregado, tende a ser padronizada e inerente a toda e qualquer relação de emprego, independentemente da situação fática, estado ou condição pessoal do trabalhador. A vulnerabilidade não requer tal padronização, permitindo maior espaço de subjetividade, desde que sem perda de proteção, com vistas a um melhor equilíbrio da relação capital-trabalho.

A essência da distinção pode ser vista na seguinte constatação: todo trabalhador é hipossuficiente na sua relação com o capital, embora nem todo trabalhador seja vulnerável. A ideia 
de hipossuficiência não conhece diferenças, enquanto a vulnerabilidade as reconhece e respeita. A hipossuficiência exige atuação estatal no mínimo no âmbito da relação de emprego, enquanto a vulnerabilidade não necessariamente fundamenta a intervenção do Estado na criação da norma heterônoma de Direito do Trabalho. A hipossuficiência exige a construção da regra trabalhista, mas não necessariamente será considerada como relevante no momento de sua interpretação ou aplicação. A ideia de vulnerabilidade não necessariamente fundamenta a construção da norma trabalhista, mas deve ser considerada no momento da sua interpretação e aplicação.

Leandro do Amaral D. de Dorneles explica a importância da noção de vulnerabilidade para o Direito do Trabalho:

\begin{abstract}
A demanda por proteção ao trabalhador, conforme entendemos, ainda é um dado inegável e inquestionável ao direito do trabalho. Mas a definição dos contornos protetivos clássicos do direito do trabalho, ocorrida no início do século passado, tinha por base uma relação então predominante e padronizada - a relação de emprego típica (arts. $2^{\circ}$ e $3^{\circ}$, CLT) - que não se apresenta mais onipresente. Atualmente nem sempre podemos identificar um padrão único de vulnerabilidades (e, consequentemente, uma demanda protetiva uniforme) comum a todos os empregados, da mesma forma que podemos perceber a combinação de diferentes vulnerabilidades em outras relações de trabalho não enquadradas nos contornos dos arts. $2^{\circ}$ e $3^{\circ}$ da CLT. A ideia de vulnerabilidade como fundamento do direito do trabalho tem por intuito aproximar a operacionalidade juslaboral das reais demandas protetivas que se apresentam em um novo mundo do trabalho, reconciliando (ou impedindo o divórcio entre) a instrumentalidade deste ramo jurídico com as reais necessidades sociais, ainda inegavelmente calcadas na demanda protetiva justificada por um desequilíbrio em suas relações jurídicas de base (DORNELES, 2013, p. 296).
\end{abstract}

É necessário aqui renovar a advertência de Konder, que fala dos riscos das categorizações.

O Brasil não pode correr o risco de desproteger trabalhadores empregados em decorrência de maior ou menor vulnerabilidade. Deve haver sempre a compreensão, na linha aqui trazida por Dorneles, de que o tratamento especial decorrente da vulnerabilidade deve se dar acima do patamar mínimo, nunca abaixo.

A vulnerabilidade nas relações de trabalho pode ser vista como fundamento da proteção estatal, como justificativa de uma tutela específica e também como instrumento de alargamento da esfera de incidência do Direito do Trabalho. Embora não seja da essência da vulnerabilidade a exigência da intervenção estatal, como ocorre com a hipossuficiência, é possível que sua compreensão justifique a atuação em perspectiva existencial, como instrumento para efetivação do princípio da Dignidade da Pessoa Humana.

A vulnerabilidade é situação de inferioridade contratual agravada por fatores de risco laboral ou pela condição pessoal do trabalhador, seja ele empregado ou não, que poderá resultar em lesão em sua esfera patrimonial ou existencial. O presente estudo desenvolve a ideia de vulnerabilidade para justificar a ampliação da proteção normativa própria do Direito do Trabalho. A partir da identificação 
de vulnerabilidades poderá o intérprete, em situações jurídicas complexas, aplicar a estrutura de proteção social justrabalhista a trabalhadores que não são empregados. Para tanto é importante compreender as categorias de vulnerabilidade que poderão possibilitar tal aplicação da norma estatal.

\subsection{VULNERABILIDADE NEGOCIAL, HIERÁRQUICA, ECONÔMICA, TÉCNICA, INFORMACIONAL, PSÍQUICA E AMBIENTAL}

A noção de vulnerabilidade permite aprofundamento fático e jurídico de acordo com a relação vivenciada pelo trabalhador no momento da entrega de sua prestação laborativa, seja ele empregado ou não. Leandro do Amaral D. de Dorneles (2013, p. 296) entende que a "ideia segundo a qual a vulnerabilidade comporta diversas desigualdades é aplicável ao direito do trabalho”, sendo importante estudar, aqui, algumas de suas diferentes perspectivas ou categorias. Além do aprofundamento fático-jurídico é possível também reconhecer tipos ou categorias diferentes de vulnerabilidade, nos termos da doutrina consumerista, civilista e trabalhista, esta historicamente mais voltada à ideia de dependência do que propriamente de vulnerabilidade. A análise das categorias de vulnerabilidade aqui será ampla, não se restringindo às situações de trabalho sem vínculo empregatício.

O presente estudo fará análise da vulnerabilidade nas perspectivas negocial, hierárquica, econômica, técnica, informacional, psíquica e ambiental. Há outras tantas categorias de vulnerabilidade, a depender do doutrinador e do âmbito da análise (jurídica, sociológica, educacional, assistencial e outros), havendo aqui escolha estratégica por aquelas situações mais comuns às relações de trabalho hodiernas.

A vulnerabilidade negocial é, nos termos da conceituação até aqui sugerida, inferioridade contratual alargada em razão da menor possibilidade que o trabalhador tem de fixar condições elementares de trabalho com o seu contratante. Pode ser reconhecida a vulnerabilidade tanto por fatores de risco laboral a que está submetido o trabalhador quanto por condição pessoal sua. Não se confunde com dependência negocial, que aqui se relaciona com hipossuficiência. Trata-se de dificuldade negocial mais aprofundada do que aquela que existe ordinariamente nas relações capitaltrabalho. É possível pensar na situação do trabalhador analfabeto, que nem sequer consegue ler seu contracheque ou recibo de pagamento, ou que não compreende as mais comezinhas ordens ou instruções escritas. É de se supor que tais trabalhadores sejam vulneráveis e que devem ter tal condição pessoal considerada nos mais diversos contextos laborais, em situações pré-contratuais, contratuais, pós-contratuais e até mesmo processuais. O mesmo se dá, também exemplificativamente, 
com trabalhadores que tenham deficiências cognitivas. É importante também compreender a vulnerabilidade negocial do trabalhador terceirizado, que muitas vezes nem sequer sabe quem é seu empregador, uma vez que se relaciona, de fato, com o tomador dos seus serviços, embora com ele não tenha vínculo jurídico. Ainda que em aparente contradição tende a se colocar em situação de vulnerabilidade negocial o “empreendedor” identificado por Ricardo Antunes (2018) como "burguês de si próprio” ou “proletário de si mesmo”, que é aquele que, sob a forma empresarial, negocia com grandes estruturas empresárias que impõem sua vontade contratual em uma falsa relação de igualdade jurídica.

A vulnerabilidade hierárquica também não se confunde com dependência hierárquica, pelo menos para os fins do presente estudo. Subordinação jurídica não se confunde, também, com vulnerabilidade hierárquica. Aqui a noção mais uma vez remete à inferioridade contratual agravada, que coloca o trabalhador em uma situação hierárquica mais fragilizada do que aquela inerente a toda e qualquer relação de emprego e que é comum até mesmo nas demais relações de trabalho. A vulnerabilidade hierárquica estará presente nas situações em que fator de risco ou a condição pessoal do trabalhador o coloca com pouca margem de resistência contra ordens abusivas do seu contratante. É possível pensar na situação do imigrante ilegal ou do escravizado contemporâneo que não conseguem, no plano fático, resistir aos mandos e aos desmandos do contratante explorador. Também pode haver vulnerabilidade hierárquica em relações de trabalho rural em que o coronelismo ainda se faz presente.

A figura do coronel não oferece espaços de diálogo e de resistências, cabendo ao peão apenas cumprir suas ordens, sejam elas quais forem. No mesmo sentido a ilegal, mas frequente, exploração do trabalho de crianças, que naturalmente não descumprem os comandos emanados dos adultos no âmbito da prestação laborativa.

A vulnerabilidade econômica também não pode ser confundida com dependência econômica, sob pena de haver coincidência entre os antigos critérios de afirmação do requisito do artigo $3^{\circ}$ da CLT na década de 1940 e os conceitos aqui apresentados. Para que o trabalhador seja vulnerável do ponto de vista econômico é necessário mais do que a ideia anterior de dependência, pois em regra geral, que contempla pouquíssimas exceções, o trabalhador depende do trabalho para subsistir. A vulnerabilidade, aqui, é decorrente de fator de risco laboral ou condição pessoal do trabalhador que o faz ficar aquém do nível da subsistência. É possível afirmar, exemplificativamente, que o novo trabalhador intermitente criado pelo direito brasileiro é vulnerável economicamente. O trabalho intermitente permite contratação sem contraprestação mensal obrigatória. Não respeita a ideia de salário mínimo mensal e nem exige o que antes era característica elementar do salário, que 
era a sua periodicidade mínima mensal. O trabalhador empregado intermitente pode não ter salário durante meses, se não for chamado por seu empregador para prestar serviços. Assim, estará vulnerável economicamente e poderá ter sua existência sensivelmente prejudicada. O mesmo se dá, mais uma vez, com o imigrante ilegal ou com o escravizado contemporâneo, pois a marca dessa exploração é o uso da força de trabalho com custo muito abaixo daquele fixado pelo mercado e pelo direito. Também os trabalhadores contratados por produção, entre eles o relevante grupo da facção na indústria da confecção, podem ser vulneráveis economicamente, pois precisam trabalhar muitas horas por dia e por semana para que possam receber o mínimo para a subsistência. A mesma ideia tem tido aplicação atual para os motoristas vinculados à plataforma digital Uber, entre outras.

A vulnerabilidade técnica não pode ser confundida com a dependência técnica que muitas vezes foi utilizada no século passado como elemento fático-jurídico caracterizador do vínculo de emprego. Nem sempre o empregador é o detentor do saber-fazer e da técnica. Há situações em que a contratação de empregado se dá exatamente por não saber o empregador desenvolver a atividade empreendida. Leandro do Amaral D. de Dorneles (2013) sugere uma outra análise sobre a vulnerabilidade técnica e identifica três interessantes perspectivas: a vulnerabilidade técnica como menor instrução profissional do trabalhador, a vulnerabilidade técnica como limitação à execução do labor e a vulnerabilidade técnica como alienação do trabalhador. A vulnerabilidade técnica aqui seria inferioridade contratual alargada em razão da menor possibilidade que o trabalhador tem de conhecer e compreender a essência de seu trabalho e o proveito que garante ao contratante. Pode ser reconhecida a vulnerabilidade tanto por fator de risco laboral a que está submetido o trabalhador quanto por condição pessoal sua. Do ponto de vista trabalhista mais amplo pode haver tal vulnerabilidade em relações estagiárias, no contrato de aprendizagem e naquelas situações em que o trabalhador é menos qualificado e tem menor instrução formal. Também pode haver vulnerabilidade técnica nas situações em que o trabalhador se enquadra na nova figura do analfabeto digital.

A vulnerabilidade informacional, ao contrário das demais, não tem paralelo na doutrina juslaboral do início dos anos de 1940 naquilo que concerne ao conceito de dependência. Trata-se de construção recente, oriunda do direito consumerista e que se caracteriza pela concentração das informações sobre produtos e serviços no fornecedor, enfraquecendo a posição do consumidor na relação. No plano da relação trabalhista é possível compreender que a vulnerabilidade informacional está relacionada à menor capacidade que certos trabalhadores têm em assimilar ou obter informações contratuais trabalhistas controladas pelo contratante. É inferioridade contratual alargada em razão da menor possibilidade que o trabalhador tem de obter informações precisas acerca de seu trabalho e de seus direitos trabalhistas. Pode ser reconhecida a vulnerabilidade tanto por fator de risco laboral a que 
está submetido o trabalhador quanto por condição pessoal sua. Embora haja importante esforço atual de contratantes com a qualidade da informação, em alguns casos ela ainda é transmitida equivocadamente ou simplesmente sonegada. É possível tomar como exemplo, relativamente comum, o trabalhador que sede suas informações cadastrais para que o contratante as utilize de modo fraudulento, muitas vezes transformando empregado em patrão, pelo menos no plano formal. Não é incomum a situação vulnerável de trabalhadores que são chamados em juízo para responder por créditos inadimplidos, como se fossem sócios de seu contratante. Outro exemplo é o de trabalhadores que desenvolvem atividade ilícita ou contravencional sem ter conhecimento efetivo do que ocorre juridicamente.

A vulnerabilidade psíquica também não encontra desenvolvimento na doutrina trabalhista, podendo ser compreendida como situação de risco decorrente de problemas psíquicos preexistentes à prestação de trabalho ou desenvolvidos durante o labor, e que agravam a inferioridade contratual do trabalhador. Pode ser reconhecida a vulnerabilidade tanto por fator de risco laboral a que está submetido o trabalhador quanto por condição pessoal sua. A preexistência de problemas psíquicos pode marginalizar o trabalhador nas fases pré-contratual e contratual do emprego, e pode também fazer com que não atue como se espera. Também é possível que problemas psíquicos possam ser desenvolvidos em razão do trabalho, como pode ocorrer, exemplificativamente, com trabalhadores vítimas de assédio moral. É possível também ocorrer vulnerabilidade psíquica com aqueles trabalhadores identificados por Ricardo Antunes (2018) como “escravos digitais”, que tendem sofrer superexploração de seu trabalho, decorrente da dificuldade ou impossibilidade de desconexão. O mesmo tende a se dar, atualmente, com trabalhadores em call-centers, dadas as especificidades e a intensidade da prestação laborativa, quase sempre terceirizada, jovem, feminina, de baixo salário, com metas excessivas e chefias abusivas. Está potencialmente presente também a vulnerabilidade psíquica nas relações de teletrabalho autônomo exclusivo, situação agravada no Brasil posteriormente à Reforma Trabalhista e em decorrência do desemprego e crises econômicas.

Cada vez mais relevante no âmbito trabalhista é a vulnerabilidade ambiental do trabalhador. Aqui a inferioridade contratual decorre do risco do ambiente de prestação laborativa, acima dos limites estabelecidos pela legislação e que pode mais fácil e previsivelmente gerar danos ao trabalhador. É inferioridade contratual alargada em razão da menor possibilidade que o trabalhador tem de se proteger dos riscos presentes no ambiente de trabalho. Com maior frequência deve ser reconhecida a vulnerabilidade por fatores de risco inerentes ao ambiente de trabalho, podendo decorrer, excepcionalmente, de condição pessoal (trabalhadores com deficiência, por exemplo). Muitos ainda são os contratantes de trabalho que não se preocupam em garantir aos trabalhadores um 
local de prestação de serviços que seja minimamente seguro. O lucro a qualquer preço faz com que alguns capitalistas economizem no ambiente e imponham ao trabalhador parte dos riscos do empreendimento. Exemplo relativamente comum é a exposição de trabalhadores à sílica (dióxido de silício), que matou e mata muitos trabalhadores brasileiros em razão da silicose. O mesmo se diga em relação ao amianto, ao benzeno e a outros cancerígenos que ainda não estão totalmente afastados da vida laborativa de muitos trabalhadores brasileiros. No âmbito do agronegócio, a cada vez mais presente utilização de agrotóxicos, que prejudica a saúde do trabalhador rural. Outro exemplo comum no mundo, principalmente no hemisfério sul, é a exploração de trabalho em minas subterrâneas, que é sabidamente potencializadora de prejuízos à saúde do trabalhador. Por fim e também relevante é o risco envolvido nas atividades de mineração, principalmente em razão da pouca segurança na construção e manutenção de barragens de rejeitos, situação comum principalmente em Minas Gerais. A insegurança do ambiente gera milhares de acidentes de trabalho fatais anualmente, o que revela a importância da compreensão jurídica sobre a vulnerabilidade ambiental do trabalhador brasileiro.

Em síntese, tais categorias de vulnerabilidade podem ser compreendidas para a melhor aplicação das regras do Direito do Trabalho, com destaque aqui para aquelas que ensejarão a identificação do trabalhador a ser tutelado pela norma jurídica heterônoma.

\subsection{VULNERABILIDADE, SUBORDINAÇÃO, SUPERSUBORDINAÇÃO, SUJEIÇÃO PESSOAL E OBJETIFICAÇÃO DO TRABALHADOR}

O estudo da vulnerabilidade no âmbito do Direito do Trabalho deve se ocupar, também, em compreender as relações existentes entre seu conceito e aqueles relacionados diretamente ao núcleo da relação de emprego, que é a subordinação jurídica. É necessário também, conforme já sinalizado, estabelecer distinções. Para tanto, e partindo sempre do conceito aqui inicialmente proposto, será relevante trazer a ideia de vulnerabilidade para o centro do Direito do Trabalho, principalmente no que concerne à sua aplicação no plano fático das diversas relações trabalhistas existentes. Tal estratégia permitirá indicar, ao final, novos sujeitos da proteção trabalhista em decorrência do conceito de vulnerabilidade.

Inobstante não seja objetivo central do presente artigo, parece ser importante sinalizar aqui, desde já, a possibilidade teórica de ser a vulnerabilidade instrumento de alargamento da esfera de incidência do Direito do Trabalho e de efetivação da Dignidade da Pessoa Humana. Na primeira perspectiva, alargamento da esfera de incidência do Direito do Trabalho, são relevantes os contornos 
jurídicos da subordinação e supersubordinação. No plano da efetivação da Dignidade da Pessoa Humana serão relevantes as ideias de sujeição pessoal e objetificação do trabalhador.

De início a subordinação jurídica, que tem sido analisada na doutrina em perspectivas objetiva e subjetiva. O prisma objetivo da subordinação fixa o conceito na prestação de serviços e não nas pessoas envolvidas na relação. Em análise subjetiva a subordinação concentra-se nas pessoas de empregado e empregador (JORGE NETO; CAVALCANTE, 2012, p. 296). Majoritariamente compreende-se subordinação tanto como observância pelo trabalhador dos comandos relativos ao modo da prestação laborativa (subordinação clássica) quanto inserção deste na dinâmica do empreendimento do contratante, observando sua estrutura de organização e funcionamento (subordinação estrutural), nos termos das lições doutrinárias de Maurício Godinho Delgado (2018). Carlos Henrique Bezerra Leite trata da subordinação, com relevante distinção relativa à expressão celetista “dependência”:

Há quem sustente que a subordinação decorre da situação de “dependência” (CLT, art. 3) do empregado em relação ao empregador. Todavia, parece-nos que o empregado não é “dependente” do empregador, e sim, a sua atividade laboral (física, mental ou intelectual) é que fica num estado de sujeição ao poder (diretivo, regulamentar e disciplinar) do empregador, sendo que este critério é, para a maioria dos doutrinadores, o mais relevante para caracterizar a relação empregatícia (LEITE, 2015, p. 150).

No Direito do Trabalho italiano a conceituação também tende a se concentrar na atividade, pois "il lavoratore mette le proprie energie lavorative a disposizione del datore di lavoro; questi le utiliza impartendo direttive che ineriscono le modalitá intrinseche dell'attivitá lavorativa, vigilando sulla loro pontuale esecuzione...” (ZARATTINI; PELUSI, 2014, p. 701). Na mesma linha estão as lições de Alfredo Montoya Melgar (2013, p. 41), no direito espanhol, que identifica a dependência ou subordinação também como "sometimiento del trabajador al poder de organización y disciplina del empresario o, dicho de otro modo, em la inserción em el circulo rector y disciplinario empresarial”. Por fim Pedro Romano Martinez (2013, p. 145), no direito português, que identifica a subordinação na relação em que o trabalhador “executa uma atividade sob a autoridade e a direção do empregador. Isso implica em que o trabalhador receba instruções e ordens, bem como esteja sujeito ao poder disciplinar do empregador”.

Subordinação, portanto, não se confunde com dependência. Também não se confunde com vulnerabilidade que, como visto, é situação de inferioridade contratual agravada por fatores de risco laboral ou pela condição pessoal do trabalhador, seja ele empregado ou não, que poderá resultar em lesão em sua esfera patrimonial ou existencial. É possível que o trabalhador seja vulnerável sem que seja empregado, sem que esteja sob subordinação jurídica. É possível, também, que um determinado 
trabalhador seja empregado, mas não seja vulnerável. Ocorre que a proteção do Direito do Trabalho não reconhece, hoje, o trabalhador autônomo vulnerável como sendo destinatário de direitos trabalhistas. É necessário, então, compreender a vulnerabilidade para além do trabalho subordinado (emprego), o que poderá justificar, pela via da melhor interpretação jurídica, o alargamento da esfera de proteção do Direito do Trabalho.

A ideia de supersubordinação do trabalhador foi desenvolvida recentemente por Jorge Luiz Souto Maior no sentido da realização da justiça social nas relações de emprego precarizadas sobretudo em razão do desrespeito a direitos trabalhistas elementares:

\footnotetext{
O supersubordinado, portanto, é o trabalhador, ser humano, reduzido à condição de força de trabalho.

O supersubordinado não é um tipo específico de trabalhador. É a designação do trabalhador, em qualquer relação de emprego, que tenha tido a sua cidadania negada pelo desrespeito deliberado e inescusável aos seus direitos constitucionalmente consagrados, entendidos, lembre-se, como direitos fundamentais.

[...]

Cumpre esclarecer que não é meramente a falta do registro que delimita a figura aqui tratada. Um empregado, devidamente registrado, por óbvio, pode ser um supersubordinado quando seus demais direitos sejam pura e simplesmente desconsiderados, como, por exemplo, trabalho em horas extras de forma ordinária com ausência do pagamento correspondente ou até mesmo com o pagamento respectivo se prestadas as horas extras de forma ordinária (variando, neste caso, apenas o grau da supersubordinação); instituição de um banco de horas que se desenvolve com nítido propósito de fraudar o direito ao recebimento de horas extras; terceirização, que nada mais é que a mercantilização do ser humano; terceirização no setor público, etc.

Há, evidentemente, graus de supersubordinação, mas, em todas as situações, destaca-se o ponto em comum que é o da tentativa deliberada de fraudar a concreta e devida aplicação dos direitos sociais. Uma desconsideração pura e simples do parâmetro jurídico da cidadania em termos trabalhistas, visando obter vantagem econômica a partir disso (SOUTO MAIOR, 2009, p. 57).
}

A supersubordinação se identifica pela ausência de reconhecimento do vínculo de emprego de um trabalhador que efetivamente se enquadra nos pressupostos fixados pelo artigo $3^{\circ}$ da CLT ou pela precarização de uma relação empregatícia formal em decorrência do desrespeito aos direitos constitucionais consagrados no ordenamento jurídico brasileiro em 1988. A essência parece ser a sonegação de direitos pelo empregador, de modo voluntário, consciente e reiterado. Tal compreensão não se vincula necessariamente a uma situação de inferioridade contratual agravada por fatores de risco laboral ou pela condição pessoal do trabalhador, seja ele empregado ou não, que poderá resultar em lesão em sua esfera patrimonial ou existencial, ou seja, à vulnerabilidade laborativa. Qualquer trabalhador pode ser supersubordinado, independentemente de estado de risco ou condição pessoal.

Para reverter a situação fático-jurídica do supersubordinado e punir o contratante, Jorge Luiz Souto Maior propõe fórmulas jurídicas contrárias ao movimento reducionista do Direito do Trabalho: 
a) a do dano social, configurado pela deliberada ou reincidente agressão à ordem jurídica dirigente econômico-social estabelecida na Constituição Federal e nos mais diversos tratados internacionais sobre a questão trabalhista;

b) a do dano pessoal, vislumbrado na supersubordinação a que se submetem os trabalhadores cujos direitos trabalhistas são vilipendiados como estratégia de obtenção de benefício concorrencial ou de auferir maior lucro e, principalmente, aqueles que são transformados, formalmente, em pessoas jurídicas ou em empresários aparentes;

c) a da subordinação estrutural, integrativa ou reticular, para ligar, efetivamente, numa perspectiva obrigacional, o autêntico capital ao trabalho, suplantando as aparências (SOUTO MAIOR, 2009, p. 64).

O que se pretende, corretamente, é evitar e punir a supersubordinação em razão do ilícito cometido e do dano causado, o que não se dá necessariamente no plano da vulnerabilidade, que, quando se trata de condição pessoal, não se pretende necessariamente evitar e muito menos punir. Também se presta o conceito de supersubordinação para a ampliação da esfera de proteção do Direito do Trabalho, ao alargar o espectro interpretativo da "dependência” fixada no artigo $3^{\circ}$ da CLT como requisito do emprego.

Wilson Ramos Filho (1994), antes da teorização de Souto Maior, porém com outro epíteto, identifica uma prática que denominou "delinquência patronal”, que consiste no descumprimento das obrigações contratuais trabalhistas pelo empregador de modo habitual, oportunidade em que se referia especificamente à terceirização. Valendo-se de tal compreensão inicial, Rodrigo Trindade de Souza estuda as punições à delinquência patronal e adverte que ela traz prejuízos não só ao empregado, mas, potencialmente, à coletividade:

As estruturas do próprio Estado, enquanto elemento da sociedade em sentido amplo, são igualmente afetadas com a delinquência patronal, pois a agressão na relação de emprego produz efeitos prejudiciais às conformações econômicas que sustentam todo o modelo de organização estatal (SOUZA, 2011, p. 583).

A supersubordinação identificada e desenvolvida recentemente por Souto Maior na doutrina justrabalhista parece guardar relação direta com a precarização das relações de trabalho, o que também pode acontecer com a vulnerabilidade, conforme será visto. Juan Carlos Zurita Pohlmann e Marcos Augusto Maliska (2012) sugerem que há no âmbito do Direito do Trabalho uma identificação, que os autores tratam como eufemismo, entre flexibilização e precarização, pois retirar a imperatividade das normas sob o argumento de redução de custos da produção é caminho de precarização dos contratos.

Temas relevantes também no que concerne à estrutura central da exploração de trabalho e sua relação com a vulnerabilidade são aqueles relacionados à sujeição pessoal e à objetificação do trabalhador, analisados, aqui, para a consagração, no plano fático, do princípio da Dignidade da Pessoa Humana. 
Em síntese, é possível compreender que sujeição pessoal do trabalhador no contexto do contrato de prestação laborativa significa excesso de controle do contratante em detrimento da vontade e da privacidade do contratado, seja ele empregado ou não. É abuso de poder diretivo, que invade esferas pessoais do trabalhador que não devem ser impactadas pela vontade do contratante. É situação daquela pessoa que é privada de sua dignidade humana em razão de excessos por parte do contratante de trabalho, seja ele empregador ou não.

Com relação à objetificação do trabalhador, a ideia é próxima daquela de sujeição pessoal, mas com ela não se confunde. A objetificação do trabalhador se relaciona com a situação em que o ser humano é tratado no contrato como se fosse um mero objeto para reprodução dos lucros do contratante. Tende a ser situação mais frequente, atualmente, do que a de sujeição pessoal. A busca pelo lucro a qualquer custo tende a transformar o trabalhador e o Direito do Trabalho em óbices transponíveis e que devem ser transpostos seja pela força do capital, seja pela intervenção do Estado neoliberal. Aqui pouco importa a dignidade de quem trabalha, desde que se preservem os interesses do capital. O raciocínio da proteção estatal no âmbito do Direito do Trabalho não só se inverte, no rumo da proteção do empregador, mas se subverte em força do capital contra o trabalho.

O conceito de vulnerabilidade pode ser utilizado como instrumento para a realização plena da dignidade da pessoa humana no contexto do trabalho, tendo como pontos de partida as ideias de sujeição pessoal e objetificação do trabalhador, embora não sejam estes, aqui, os temas centrais do presente estudo.

\section{NOVOS SUJEITOS DA PROTEÇÃO TRABALHISTA: A VULNERABILIDADE DO TRABALHADOR NÃO EMPREGADO COMO JUSTIFICATIVA DA PROTEÇÃO ESTATAL}

A vulnerabilidade é situação de inferioridade contratual agravada por fatores de risco laboral ou pela condição pessoal do trabalhador, seja ele empregado ou não, que poderá resultar em lesão em sua esfera patrimonial ou existencial. Nas situações de vulnerabilidade marcadas por fatores de risco laboral devem o empregador e o Estado atuar no sentido de atenuar as condições que podem levar aos prejuízos patrimoniais ou existenciais do trabalhador. Com relação às situações de vulnerabilidade marcadas por condição pessoal do trabalhador, o papel do Estado é no sentido de garantir proteção normativa efetiva ao contratante inferiorizado. Assim, pode ser reconhecida a vulnerabilidade tanto por fatores de risco laborais a que está submetido o trabalhador quanto por condição pessoal dele. Se a vulnerabilidade é decorrente de fator de risco, é possível que atue o Estado no cerne da situação vulnerável, para melhorar as condições de trabalho. Se decorre a vulnerabilidade 
de condição pessoal, não deve o Estado atuar sobre o cerne da vulnerabilidade, cabendo apenas melhorar a inserção laborativa da pessoa, sempre no sentido de garantir proteção normativa àquele que trabalha em situação de vulnerabilidade.

Atualmente a vulnerabilidade do trabalhador decorre, em diversas situações fáticas, da precarização do trabalho, cada vez mais presente no Brasil e no mundo. Ricardo Antunes percebe a precarização do trabalho como regra:

\begin{abstract}
Trata-se de uma hegemonia da lógica financeira que, para além de sua dimensão econômica, atinge todos os âmbitos da vida social, dando um novo conteúdo aos modos de trabalho e de vida, sustentados na volatilidade, na efemeridade e na descartabilidade sem limites. É a lógica do curto prazo, que incentiva a "permanente inovação" no campo da tecnologia, dos novos produtos financeiros e da força de trabalho, tornando obsoletos e descartáveis os homens e mulheres que trabalham. São tempos de desemprego estrutural, de trabalhadores e trabalhadoras empregáveis no curto prazo, por meio das (novas e) precárias formas de trabalho, em que terceirização, informalidade, precarização, materialidade e imaterialidade são mecanismos vitais, tanto para a preservação quanto para a ampliação da sua lógica. (ANTUNES, 2018, p. 153-154).
\end{abstract}

Ao presente estudo cabe compreender a ideia de vulnerabilidade com vistas à ampliação da esfera de proteção trabalhista para trabalhadores que não são empregados. Não se pretende aqui obviamente esgotar a temática, mas apenas apontar caminhos que poderão ensejar novas compreensões sobre a vulnerabilidade no Direito do Trabalho e novos estudos sobre o tema. Em síntese o que se pretende é a identificação de novos sujeitos decorrentes do conceito juslaboral de vulnerabilidade.

\title{
2.1 AMPLIAÇÃO DA ESFERA DE PROTEÇÃO TRABALHISTA PARA ALÉM DO EMPREGO
}

Propostas de ampliação da esfera de proteção trabalhista não são novas e nem se fundamentam necessariamente no conceito de vulnerabilidade. Historicamente o Estado brasileiro percebeu a construção de regras heterônomas de regulação das relações capital-trabalho sob a ótica quase exclusiva da relação de emprego. É claro que a prevalência da proteção à relação de emprego se justifica histórica, social, política e economicamente, afinal de contas trata-se da modalidade mais importante, do ponto de vista social e econômico, “de pactuação de prestação de trabalho existente nos últimos duzentos anos, desde a instauração do sistema econômico contemporâneo, o capitalismo” (DELGADO, 2018, p. 334). Mas há cada vez mais espaço social e necessidade de ampliação da proteção trabalhista.

Estratégias interpretativas de ampliação da esfera de proteção do Direito do Trabalho para além do emprego estão em consonância com o caput do artigo $7^{\circ}$ da Constituição da República, que 
não restringiu a incidência dos direitos sociais trabalhistas aos empregados, tendo preferido garantilos aos trabalhadores genericamente considerados. Vale lembrar que a referida norma se refere aos direitos dos “trabalhadores urbanos e rurais", e não aos direitos dos empregados urbanos e rurais.

A consagração de direitos mínimos a trabalhadores não empregados se situa no contexto expansionista do Direito do Trabalho no Brasil. O Professor Maurício Godinho Delgado (2017, p. 116) destaca três possibilidades básicas de expansionismo do Direito do Trabalho: "a crescente e contínua busca de efetividade”, a “ampliação do conceito de relação de emprego, via subordinação”, além da "extensão do Direito do Trabalho a relações de trabalho, ultrapassando o marco clássico da simples relação de emprego". De início interessa ao presente estudo a terceira possibilidade expansionista, que consiste em ampliação da proteção estatal a algumas relações de trabalho que não caracterizam vínculo empregatício.

As teorias expansionistas do Direito do Trabalho pretendem o reconhecimento de novos sujeitos da proteção especial, visto que no sistema capitalista é por meio do trabalho que o cidadão consegue, como regra geral, sobreviver com dignidade. Sendo assim, deveria interessar ao Estado a ampliação da esfera de proteção, com direitos trabalhistas garantidos a um maior número de cidadãos, como política pública de inclusão social e justa distribuição de renda.

O que o presente estudo sugere, então, é uma nova abordagem para o tema, na perspectiva da mais ampla proteção estatal àqueles que vivem do trabalho. A ideia básica é relativamente simples: se a relação contratual de trabalho não é de emprego por ausência de requisito(s) do artigo $3^{\circ}$ da CLT, mas está presente a inferioridade contratual agravada que pode resultar em lesão na esfera patrimonial ou existencial do trabalhador, então deve-se garantir a ele a aplicação da regra trabalhista, sobretudo, aqui, a de matriz constitucional.

A estratégia do presente estudo, que é incipiente no que concerne à aplicação das teorias de vulnerabilidade no âmbito prático das relações capital-trabalho, será retomar brevemente algumas categorizações que poderão permitir a aplicação da normatização heterônoma trabalhista para além do emprego.

É possível partir de categorizações de vulnerabilidade (negocial, hierárquica, econômica, técnica, informacional, psíquica e ambiental) consagradas na doutrina para que seja possível reconhecer novos sujeitos da proteção sempre que em uma relação de trabalho sem vínculo de emprego esteja presente a vulnerabilidade daquele que vive do seu trabalho.

A compreensão de extensão de direitos trabalhistas aos trabalhadores não empregados, porém vulneráveis, tem respaldo na Constituição da República, artigo $7^{\circ}$, caput; artigo $1^{\circ}$, inciso IV; artigo $6^{\circ}$ e artigo 193. Em todos os dispositivos aqui referenciados a Constituição da República 
direciona a proteção estatal ao trabalho, e não somente ao emprego. Sendo assim, a proteção trabalhista, principalmente relativa aos direitos constitucionais sociais, deve ser direcionada também ao trabalhador vulnerável que não é empregado de seu contratante. Aquele que se apropria do trabalho deve promover diretamente a consagração dos direitos trabalhistas, haja vista a eficácia horizontal dos direitos fundamentais.

\subsection{NOVOS SUJEITOS DA PROTEÇÃO TRABALHISTA DECORRENTES DO CONCEITO JUSLABORAL DE VULNERABILIDADE}

A vulnerabilidade das pessoas que no mercado só têm força de trabalho para vender deve ensejar seu reconhecimento como novos sujeitos da proteção estatal trabalhista. O desafio é tornar juridicamente viável, ainda que em parte, a compreensão sociológica de Ricardo Antunes sobre quem é, hoje, a classe-que-vive-do-trabalho no Brasil:

Partiremos da formulação de que ela compreende a totalidade dos assalariados, homens e mulheres que vivem da venda da sua força de trabalho e que são despossuídos dos meios de produção, conforme a definição marxiana.

[...]

A classe trabalhadora, portanto, é composta - e isso é decisivo hoje - da totalidade dos assalariados, em todas as suas distintas modalidades de inserção no mundo do trabalho, incluindo aqueles subempregados, na informalidade e desempregados.

Em nossa concepção ampliada estão excluídos da classe trabalhadora os gestores do capital, que são parte constitutiva da classe dominante, pelo papel central que têm no controle, na hierarquia, no mando e na gestão do capital e de seu processo de valorização, bem como os pequenos empresários, a pequena burguesia urbana e rural, que é detentora - ainda que em menor escala - dos meios de sua produção. Estão excluídos também aqueles que vivem de juros e da especulação.

Então, compreender a classe trabalhadora hoje, de modo abrangente, implica entender esse conjunto heterogêneo, ampliado, complexo e fragmentado de seres sociais que vivem da venda da sua força de trabalho, que são assalariados e desprovidos dos meios de produção (ANTUNES, 2018, p. 91).

O desafio aqui proposto, que não é expresso e explícito na obra citada de Ricardo Antunes, é garantir direitos trabalhistas a toda a classe-que-vive-do-trabalho desde que o trabalhador seja vulnerável, mesmo que não seja empregado.

Mais uma vez a estratégia do presente estudo incipiente será retomar brevemente alguns exemplos práticos de trabalhadores vulneráveis e aplicar a regra constitucional do artigo $7^{\circ}$ em sua avença.

É possível pensar como novos sujeitos da proteção trabalhista o “empreendedor" identificado por Ricardo Antunes (2018) como "burguês de si próprio" ou "proletário de si mesmo", os menores que são explorados, os trabalhadores em contratos de facção, os motoristas contratados via plataforma Uber e outras, os trabalhadores em atividades contravencionais sem potencial ofensivo 
e o autônomo exclusivo no teletrabalho. Tais situações de trabalho aqui descritas são meramente exemplificativas, na expectativa de que seja possível desenvolver outras tantas com a mesma estratégia interpretativa e de aplicação do direito.

Antes da análise específica, entretanto, é necessário reafirmar que não se trata aqui de situações de fraudes tendentes a encobrir ou afastar a relação de emprego. Trata-se de relação de trabalho sem um ou mais requisitos do emprego e que ainda assim merecerão tutela estatal trabalhista, em perspectiva constitucional, em razão da vulnerabilidade do trabalhador na avença que mantém com aquele que lhe explora força produtiva.

No que concerne aos empreendedores que são proletários de si mesmos, devem os contratantes, a sociedade e o Estado reconhecer a vulnerabilidade daquele que como pessoa física ou jurídica se relaciona em posição de fraqueza contratual com alguém que se aproveita de sua força de trabalho. A partir de tal reconhecimento incidirão na avença mantida todos os direitos sociais trabalhistas consagrados no artigo $7^{\circ}$ da Constituição da República.

Sobre os menores que são explorados e que não preenchem os requisitos do emprego (CLT, artigo $3^{\circ}$ ) ou para os quais a avença é invalidada por incapacidade laborativa (CLT, artigos 402 e 403) deve o Estado intervir não só para fazer cessar a exploração indevida, mas, também, para impor ao explorador a satisfação pecuniária referente aos direitos sociais trabalhistas consagrados no artigo $7^{\circ}$ da Constituição da República. O mesmo se aplica, sob outros fundamentos jurídicos, àqueles trabalhadores que desenvolvem atividade contravencional sem potencial ofensivo, como é o caso dos apontadores do jogo do bicho. A invalidade da avença decorrente de ilicitude deverá ser afastada, para que sejam reconhecidas a vulnerabilidade do trabalhador destinatário de tutela estatal e seus direitos constitucionais sociais.

Quanto aos trabalhadores em contratos de facção, ainda que autônomos, devem ser reconhecidos como vulneráveis, devendo o Estado garantir, também e no mínimo, os direitos sociais trabalhistas consagrados no artigo $7^{\circ}$ da Constituição da República.

Em relação aos motoristas contratados via plataforma Uber e outras, ainda que os tribunais trabalhistas relutem em reconhecer vínculo empregatício, a simples vulnerabilidade deverá ensejar a concretização de direitos sociais trabalhistas consagrados no artigo $7^{\circ}$ da Constituição da República, mesmo sendo o trabalhador autônomo ou não se reconhecendo onerosidade objetiva na avença.

Por fim a figura do autônomo exclusivo no teletrabalho. Por definição trata-se de autônomo, o que afasta a clássica proteção celetista. Ocorre que se houver vulnerabilidade laborativa em decorrência de exclusividade da entrega de trabalho a um único contratante deverá incidir, também aqui, direitos sociais trabalhistas consagrados no artigo $7^{\circ}$ da Constituição da República. 
São apenas alguns exemplos iniciais de aplicação da vulnerabilidade trabalhista em relações que não são de emprego, mas que exigem a tutela trabalhista ainda que inicialmente na perspectiva dos direitos constitucionais sociais.

\section{CONCLUSÃO}

A vulnerabilidade na perspectiva das relações capital-trabalho pode ser compreendida como situação de inferioridade contratual agravada por fatores de risco laboral ou pela condição pessoal do trabalhador, seja ele empregado ou não, que poderá resultar em lesão em sua esfera patrimonial ou existencial. A definição justrabalhista de vulnerabilidade é necessariamente relacional, e não situacional, como preferem os autores de Direito Privado em geral. A situação do trabalhador só interessa para o Direito do Trabalho, em perspectiva restrita ou ampliada, se e quando ele se insere em uma relação com alguém que lhe absorve mão de obra ou saber-fazer. Enfim, a vulnerabilidade para fins de Direito do Trabalho está necessariamente vinculada à inserção laborativa contratual do trabalhador (relação de trabalho ou emprego), sem a qual não se justifica a análise específica.

É possível e em determinadas situações necessária a identificação de categorias de vulnerabilidade, sem que se pretenda, com isso, criar categorias distintas de proteção ao trabalhador. Vulnerabilidade negocial é inferioridade contratual alargada em razão da menor possibilidade que o trabalhador tem de fixar condições elementares de trabalho com o seu contratante. Vulnerabilidade hierárquica é inferioridade contratual agravada que coloca o trabalhador em uma situação hierárquica mais fragilizada do que aquela inerente a toda e qualquer relação de emprego e que é comum até mesmo nas demais relações de trabalho. Vulnerabilidade econômica é decorrente de um estado de risco ou condição pessoal do trabalhador que o faz ficar aquém do nível da subsistência. Vulnerabilidade técnica é inferioridade contratual alargada em razão da menor possibilidade que o trabalhador tem de conhecer e compreender a essência de seu trabalho e o proveito que garante ao contratante. Vulnerabilidade informacional é inferioridade contratual alargada em razão da menor possibilidade que o trabalhador tem de obter informações precisas acerca de seu trabalho e de seus direitos. Vulnerabilidade psíquica é situação de risco decorrente de problemas psíquicos preexistentes à prestação de trabalho ou desenvolvidos durante o labor e que agravam a inferioridade contratual do trabalhador. Por fim, a vulnerabilidade ambiental do trabalhador é inferioridade contratual alargada em razão da menor possibilidade que o trabalhador tem de se proteger no ambiente de trabalho.

Não é razoável compreender que hipossuficiência e vulnerabilidade têm a mesma conceituação técnica. Tratando-se especificamente da relação jurídica de emprego é possível afirmar 
que todo empregado é hipossuficiente em razão de se posicionar contratualmente como tal na avença empregatícia. Todo trabalhador é hipossuficiente em relação ao contratante de seu trabalho, o que não ocorre necessariamente com a vulnerabilidade. A hipossuficiência exige atuação estatal no mínimo no âmbito da relação de emprego, enquanto a vulnerabilidade não necessariamente fundamenta a intervenção do Estado na criação da norma heterônoma de Direito do Trabalho. A hipossuficiência exige a construção da regra trabalhista, mas não necessariamente será considerada como relevante no momento de sua interpretação ou aplicação. A ideia de vulnerabilidade não necessariamente fundamenta a construção da norma trabalhista, mas deve ser considerada no momento da sua interpretação e aplicação.

O objetivo central do presente estudo foi a fixação de conceitos justrabalhistas de vulnerabilidade e sua distinção em relação a outros temas e institutos, sobretudo hipossuficiência. Não obstante tal centralidade, é possível desde já iniciar debates em torno da aplicação prática do conceito de vulnerabilidade no Direito do Trabalho brasileiro. É possível, ainda que de modo incipiente, indicar estratégias para ampliação da esfera de proteção trabalhista para além de emprego, tendo a vulnerabilidade laborativa como ponto de partida para tanto. Da mesma forma é possível pensar em novos sujeitos da proteção trabalhista decorrentes do conceito juslaboral de vulnerabilidade.

Apresentados os conceitos e as principais distinções, caberá aos estudiosos das relações jurídicas entre capital e trabalho sua utilização para a construção de estratégias interpretativas da norma posta tendentes à ampliação da proteção laboral, para que cada vez mais trabalhadores sejam inseridos na esfera protetiva estatal.

\section{REFERÊNCIAS}

ANTUNES, Ricardo. O Privilégio da Servidão: o novo proletário de serviços na era digital. São Paulo: Boitempo, 2018.

ANTUNES, Ricardo; DRUCK, Graça. A terceirização sem limites: a precarização do trabalho como regra. O Social em Questão, Ano XVIII, n. 34, 2015.

DELGADO, Maurício Godinho. Curso de Direito do Trabalho. 16. ed. São Paulo: LTr., 2017. DELGADO, Maurício Godinho. Curso de Direito do Trabalho. 17. ed. São Paulo: LTr., 2018. DORNELES, Leandro do Amaral D. de. Hipossuficiência e Vulnerabilidade na Teoria Geral do Direito do Trabalho Contemporânea. Revista LTr., ano 77, março de 2013. São Paulo: LTr., 2013. 
DRUCK, Graça. Trabalho, Precarização e Resistências: Novos e Velhos Desafios? Caderno CRH, Salvador, v. 24, n. spe 01, p. 35-55, 2011.

HIPOSSUFICIENTE. In: HOUAISS, Antônio; VILLAR, Mauro de Salles; FRANCO, Francisco Manoel de Melo. Dicionário Houaiss da língua portuguesa. 1. ed. Rio de Janeiro: Objetiva, 2009.

JORGE NETO, Francisco Ferreira; CAVALCANTE, Jouberto de Quadros Pessoa. Direito do Trabalho. 6. ed. São Paulo: Atlas, 2012.

KONDER, Carlos Nelson. Vulnerabilidade Patrimonial e Vulnerabilidade Existencial: por um sistema diferenciador. Revista de Direito do Consumidor, v. 99, p. 101-123, 2015.

LEITE, Carlos Henrique Bezerra. Curso de Direito do Trabalho. 6. ed. São Paulo: Saraiva, 2015.

MARQUES, Cláudia Lima; MIRAGEM, Bruno. O Novo Direito Privado e a Proteção dos

Vulneráveis. 2. ed. São Paulo: Revista dos Tribunais, 2014.

MARTINEZ, Pedro Romano. Direito do Trabalho. 6. ed. Coimbra: Almedina, 2013.

MELGAR, Alfredo Montoya. Derecho del Trabajo. 34. ed. Madrid: Tecnos, 2013.

MÉSZÁROS, István. A Crise Estrutural do Capital. São Paulo: Boitempo, 2009.

POCHMANN, Márcio. Trabalho sob Fogo Cruzado: exclusão, desemprego e precarização no final do século. São Paulo: Contexto, 1999.

POHLMANN, Juan Carlos Zurita; MALISKA, Marcos Augusto. A Precarização das Relações de Trabalho e o Estado Constitucional. In: RAMOS FILHO, Wilson. Trabalho e Regulação: As Lutas Sociais e as Condições Materiais da Democracia. Vol. I. Belo Horizonte: Fórum, 2012.

PREFEITURA MUNICIPAL DE BELO HORIZONTE. Secretaria Municipal Adjunta de Assistência Social. Dicionário de termos técnicos da assistência social. Belo Horizonte: ASCOM, 2007.

PRONI, Marcelo Weishaupt. Trabalho decente e vulnerabilidade ocupacional no Brasil. Economia e Sociedade, Campinas, v. 22, n. 3 (49), p. 825-854, dez. 2013.

RAMOS FILHO, Wilson. O Enunciado n. 331 do TST: terceirização e delinquência patronal. Síntese Trabalhista. Porto Alegre, n. 58, p. 110-122, abr. 1994.

SOUTO MAIOR, Jorge Luiz. Supersubordinação: invertendo a lógica do jogo. Revista Síntese Trabalhista e Previdenciária, n. 242, 2009.

SOUZA, Rodrigo Trindade de. Punitive damages e o direito do trabalho brasileiro - adequação das condenações punitivas para a necessária repressão da delinquência patronal. Revista LTr. São Paulo. vol. 75, n. 05, maio 2011.

THEODORO JUNIOR, Humberto. Direitos do Consumidor: a busca de um ponto de equilíbrio entre as garantias do código de defesa do consumidor e os princípios gerais do direito civil e do direito processual civil. Rio de Janeiro: Forense, 2004. 
VULNERÁVEL. In: HOUAISS, Antônio; VILLAR, Mauro de Salles; FRANCO, Francisco Manoel de Melo. Dicionário Houaiss da língua portuguesa. 1. ed. Rio de Janeiro: Objetiva, 2009.

ZARATTINI, Pietro; PELUSI, Rosalba. Manuale Lavoro. 10. ed. Milano: Novecento Editore, 2014.

Amauri Cesar Alves

Doutor, Mestre e Bacharel em Direito pela Pontifícia Universidade Católica de Minas Gerais (PUC Minas). Professor Adjunto na Universidade Federal de Ouro Preto (UFOP), Graduação e Mestrado. Coordenador do Grupo de Estudos de Direito do Trabalho (GEDIT) da Universidade Federal de Ouro Preto. Membro do Grupo Novos Direitos Privados e Vulnerabilidades. Avaliador do Sistema Nacional de Avaliação da Educação Superior BASis INEP/DAES/MEC. E-mail: amauri.alves.dte@gmail.com 